\title{
Evaluation of Drum Seeder in Rice (Oryza sativa $L$. under Different Spacing's
}

\author{
R. Srinivasa Rao*, M. Venkatramulu, J. Hemantha Kumar and P. Raghurami Reddy \\ Professor Jayashankar Telangana State Agricultural University, India \\ District Agricultural Advisory and Transfer of Technology Centre, \\ Khammam, 507 003, Telangana, India \\ *Corresponding author
}

\section{A B S T R A C T}

The on farm trial was carried out in farmers fields in five locations of Khammam District of Central Telangana Zone in three consecutive seasons of kharif 2015,

\section{Keywords}

$\mathrm{C}$ : $\mathrm{B}$ ratio, Drum seeder, Grain yield, Panicles, Harvest Index and Rice

\section{Article Info}

Accepted:

22 March 2020

Available Online:

10 April 2020 2016 and 2017 by District Agricultural Advisory and Transfer of Technology Centre, Khammam belongs to Professor Jayashankar Telangana State Agricultural University, Hyderabad to study on evaluation of drum seeder in rice under different spacing's. Four treatments were imposed to find out proper spacing with drum seeder in direct sowing rice viz., $T_{1}-30 \mathrm{~cm}$ spacing, $T_{2}-25 \mathrm{~cm}$ spacing, $T_{3}-20$ $\mathrm{cm}$ and $\mathrm{T}_{4^{-}}$Transplanting under delayed condition. The investigation result on pooled basis showed that the maximum plant height $(83.2 \mathrm{~cm})$ and more no of tillers (405.3) $\mathrm{m}^{-2}$, Significantly maximum number of Panicles/ $\mathrm{m}^{-2}$ (387.8), Length of Panicle $(18.3 \mathrm{~cm})$, number of grains per panicle (186.7), Straw Yield (10102 $\mathrm{kg} / \mathrm{ha})$, Harvest Index (40.6\%) and grain yield (6945 kg/ha) were recorded with 30 $\mathrm{cm}$ spacing drum seeder $\left(T_{1}\right)$ than other treatments followed by $T_{2^{-}}(25 \mathrm{~cm}$ spacing).The experimental results revealed that the significant influence on both growth and yield attributes as well as on economics of rice. The lowest plant height $(73.3 \mathrm{~cm})$, plant stands (25.0) and less number of tillers (309.3) per unit area and grain yield $(5370 \mathrm{~kg} / \mathrm{ha})$ were recorded in farmers practice (T4) due to delayed practices no of tillers was very low as well as poor plant stand per unit area than other treatments.

\section{Introduction}

Transplanting is the most common method in rice cultivation in low land rice. In Khammam District, Telangana the major area of rice cultivation is under tank fed irrigation and it's depend on rainfall similarly 40 per cent area was depend on NSP canal also. In many years over aged seedlings are used for planting due to delayed monsoon. The raising nursery and manual transplanting are labour intensive and costly operations. Transplanting is not 
profitable due to high labour wages and the problem of non- availability of labour during peak period of operation (Singh et al., 2005). Transplanting alone costs equal about $15 \%$ of total rice production cost and delayed transplanting due to labour shortage causes sustainable loss in yield (Ponnuswamy et al., 1999). Transplanting also enhances the crop duration by 7-10 days. On the other hand broadcasting causes uneven plant population in puddle condition and seed rate also high. Therefore, there is need alternate methods to replace transplanting to tackle the problems of high cost of production and labour scarcity. The alternative methods such as dry seeding in aerobic soil conditions or wet seeding in aerobic or anaerobic soil condition can be choose depending up on the circumstances of the location. In irrigated areas dry or wet seeding can be done. It saves the irrigation water as seedbed preparation is done in dry or moist conditions. In dry seeding fields, weeding cost is high. By adopting line seeding in puddled fields weeding cost is drastically reduced due to use of chemical weedcides or mechanical weeders. In case of wet seeding method, pre-germinated seeds are broadcasted in puddle soil and are generally practiced in irrigated and favorable low land conditions. Wet seeding fields needed proper leveling and drainage for better crop stand whereas in water logged condition seed germination percent is reduced. Even though under drum seeder technology some farmers were noticed the problems in drum seeding cultivation especially they encountered on inconvenience during mechanical weeding operation in between rows with cono weeders or power weeders with the use of present exist $20 \mathrm{~cm}$ drum seeders. On farm testing has been identified as tool to refine or modify the technology for adoption by farmers. Keeping in view, the present study was conducted in farmers' field to find out the suitable spacing to reduce the inconvenient during weeding operation and better yield with use of $30 \mathrm{~cm}$,
$25 \mathrm{~cm}$ and $20 \mathrm{~cm}$ spacing drum seeders in comparison with traditional method of paddy cultivation.

\section{Materials and Methods}

The District Agricultural Advisory and Transfer of Technology Centre (DAATT Centre), Khammam has conducted the on farm trials entitled evaluation of drum seeder in rice under different spacing's during kharif season of 2015, 2016 and 2017 in five locations of Khammam district. The soils of the experimental locations were medium to deep sandy clay loam texture with PH 7.6, organic carbon 0.52 . The experiment was laid out in five randomized locations with four treatments. Two acres was allotted as a representative area for testing the performance of drum seeder in farmer's fields with four treatments Viz., T1-30 cm drum seeder,(made with local casing pipe) T2- 25 $\mathrm{cm}$ drum seeder T3- $20 \mathrm{~cm}$ drum seeder and T4-Farmers practice (Transplanting) under delayed conditions. For direct sowing using drum seeder, the paddy seeds were soaked in water for 24 hours, sometimes 24 hours incubated in gunny bags depend up on variety and weather temperature. Sprouted seeds were sown using drum seeder @ 30 kg/ha seed rate. The field was well puddle and leveled after draining the standing water. After puddling, the field is left for 1-2 days for settling of puddled soil. The pre germinated paddy seeds were sown in 8 line and 6 lines using drum seeders. The total an average rainfall received during three years cropping season was $1045 \mathrm{~mm}$. The germinated seeds of long duration rice varieties like MTU-1061and BPT-5204 were sown on July first week in three years. The seed rate adopted for direct sowing of rice was $30-35 \mathrm{~kg} / \mathrm{ha}$. The crop was fertilized with 120:60:50 kg NPK/ha. Full dose of P, half dose of $\mathrm{K}$ applied at the time of sowing remaining half at the time of panicle initiation 
stage and one third dose of $\mathrm{N}$ applied at 20 DAS, remaining one third dose of $\mathrm{N}$ were applied at tillering stage and last one third dose of $\mathrm{N}$ applied at panicle initiation stage. Post emergence herbicides were applied at 15 DAS with the help of knapsack sprayer fitted with flat fan nozzle at spray volume 300 1/ha. Awareness on use of drum seeder was created by campaigns and field visits. This had evoked interest among the farmers in adopting direct sowing paddy using drum seeder. Trainings, frontline demonstrations, on farm testing, field days, Exposure visits and Rythusadassus have been used systematically during 2015-2017 to convince and disseminate the direct sowing paddy using drum seeder to the farming community of the Khammam District. The observations on growth attributes were taken at different intervals and yield attributing characters like no of panicles $\mathrm{m}^{-2}$, panicle length, no of grains per panicle and test weight were recorded at harvest. The cost of cultivation was worked out based on the labour and input cost incurred towards rice cultivation in different treatments. Harvest Index was calculated using the formula and expressed in percentage.

\section{Grain Yield \\ Harvest Index (\%) = -------- X 100 \\ Grain Yield +Straw Yield}

\section{Data analysis}

The data was analyzed using ANOVA and the least significant difference (LSD) values at $5 \%$ level of significance were calculated and used the RBD test significant difference between treatment means.

\section{Results and Discussion}

\section{Growth attributes}

The data on progressive of growth and development of rice as significantly influenced by the drum seeder sowing under different spacing's during kharif season were recorded at periodical intervals in cropping season. The plant height was increased continuously up to maturity. The increase in plant height was rapid during 30 to 90 days after sowing and there after it was slow down. $30 \mathrm{~cm}$ spacing drum seeder $\left(\mathrm{T}_{1}\right)$ recorded significantly maximum plant height $(83.2 \mathrm{~cm})$ and more no of tillers $(405.3) \mathrm{m}^{-2}$ in spite of less plant stand than other treatments, due to optimum spacing keep weed free condition with use of power weeder two times there by no competition for nutrient uptake between weeds and rice plants and produced more number of tillers with utilization of natural resources and nutrient absorption. However $25 \mathrm{~cm}$ spacing drum seeder $\left(\mathrm{T}_{2}\right)$ was recorded significantly maximum plant height $(79.9 \mathrm{~cm})$ and more no of tillers (353.4) $\mathrm{m}^{-2}$ over farmer practice $\left(\mathrm{T}_{4}\right)$ similar research finding were revealed by Padmaja et al., (1998) and Reddy et al., (1986). Among all the treatments more number of plants (35.7) per $\mathrm{m}^{-2}$ was recorded with $20 \mathrm{~cm}$ spacing drum seeder $\left(\mathrm{T}_{3}\right)$ because less spacing create number of plant population as well as low (322.9) tillering capacity was observed due to heavy competition between plants than $30 \mathrm{~cm}$ spacing drum seeder $\left(\mathrm{T}_{1}\right)$ and $25 \mathrm{~cm}$ spacing drum seeder $\left(\mathrm{T}_{2}\right)$ treatments. Similarly $\mathrm{T}_{3}$ and $\mathrm{T}_{4}$ treatment were on par with each other in all the seasons. Among all the treatments 30 $\mathrm{cm}$ spacing drum seeder $\left(\mathrm{T}_{1}\right)$ has proved for better establishment of plant population and produced more tillers per unit area followed by $25 \mathrm{~cm}$ spacing drum seeder $\left(\mathrm{T}_{2}\right)$ was best treatment compare to $\mathrm{T}_{3}$ and $\mathrm{T}_{4}$ treatments. The lowest plant height $(73.3 \mathrm{~cm})$, plant stands (25.0) and less number of tillers (309.3) per unit area were recorded in farmers practice (T4) due to delayed practices no of tillers was very low as well as poor plant stand per unit area than other treatments. Similar findings were reported by Baloch et al., (2002) (Table 1-4). 
Table.1 The growth attributes of rice were influenced by drum seeder under of different spacing's

\begin{tabular}{|c|c|c|c|c|c|c|c|c|c|c|c|c|}
\hline \multirow[t]{2}{*}{ Treatments } & \multicolumn{4}{|c|}{ Plant Height (cm) } & \multicolumn{4}{|c|}{ No of Plants $/ \mathrm{m}^{-2}$} & \multicolumn{4}{|c|}{ No of Tillers/ $\mathrm{m}^{-2}$} \\
\hline & 2015 & 2016 & 2017 & Pooled & 2015 & 2016 & 2017 & Pooled & 2015 & 2016 & 2017 & Pooled \\
\hline T1- $30 \mathrm{~cm}$ spacing & 86.4 & 82.7 & 80.6 & 83.2 & 31.4 & 31.7 & 29.4 & 30.8 & 442.7 & 447.4 & 326.6 & 405.3 \\
\hline T2-25 cm spacing & 83.0 & 78.5 & 78.4 & 79.9 & 33.6 & 32.6 & 31.8 & 32.6 & 368.4 & 379.7 & 312.3 & 353.4 \\
\hline T3-20 cm spacing & 77.6 & 75.4 & 75.2 & 76.0 & 35.3 & 37.8 & 34.2 & 35.7 & 337.8 & 344.4 & 286.7 & 322.9 \\
\hline $\begin{array}{l}\text { T4-Farmers practice } \\
\text { (Delayed transplanting) }\end{array}$ & 72.5 & 74.0 & 73.4 & 73.3 & 24.2 & 27.5 & 23.4 & 25.0 & 318.4 & 328.2 & 281.5 & 309.3 \\
\hline SEm \pm & 3.3 & 2.3 & 2.4 & 2.4 & 2.8 & 3.2 & 3.4 & 3.2 & 19.4 & 21.5 & 14.4 & 21.6 \\
\hline C.D. at 5\% & 8.4 & 5.2 & 5.3 & 6.1 & 6.2 & 8.3 & 8.6 & 7.8 & 48.6 & 50.6 & 28.6 & 50.4 \\
\hline
\end{tabular}

Table.2 Yield attributes of rice were influenced by drum seeder under of different spacing's

\begin{tabular}{|c|c|c|c|c|c|c|c|c|c|c|c|c|}
\hline \multirow[t]{2}{*}{ Treatments } & \multicolumn{4}{|c|}{ No of Panicles/ $\mathbf{m}^{-2}$} & \multicolumn{4}{|c|}{ Length of Panicle (cm) } & \multicolumn{4}{|c|}{ No of grains per panicle } \\
\hline & 2015 & 2016 & 2017 & $\begin{array}{c}\text { Poole } \\
\text { d }\end{array}$ & 2015 & 2016 & 2017 & Pooled & 2015 & 2016 & 2017 & Pooled \\
\hline T1- $30 \mathrm{~cm}$ spacing & 423.3 & 425.5 & 314.7 & 387.8 & 18.4 & 18.7 & 17.8 & 18.3 & 186.4 & 192.4 & 181.5 & 186.7 \\
\hline T2-25 cm spacing & 345.5 & 356.2 & 291.4 & 331.0 & 17.2 & 17.5 & 17.0 & 17.2 & 182.3 & 184.6 & 180.2 & 182.3 \\
\hline T3-20 cm spacing & 316.6 & 318.7 & 263.6 & 299.6 & 16.8 & 17.3 & 16.6 & 16.9 & 176.3 & 178.7 & 172.5 & 175.8 \\
\hline $\begin{array}{l}\text { T4-Farmers practice } \\
\text { (Delayed transplanting) }\end{array}$ & 296.4 & 304.8 & 258.2 & 286.4 & 16.5 & 16.8 & 16.3 & 16.5 & 175.2 & 174.5 & 174.3 & 174.6 \\
\hline SEm \pm & 28.6 & 19.4 & 13.0 & 21.6 & 0.6 & 0.6 & 0.4 & 0.5 & 2.7 & 3.5 & 2.8 & 3.0 \\
\hline C.D. at 5\% & 76.4 & 50.8 & 32.2 & 55.3 & 1.5 & 1.6 & 1.4 & 1.4 & 6.8 & 10.0 & 5.8 & 7.5 \\
\hline
\end{tabular}


Table.3 Yield and yield attributes of rice were influenced by drum seeder under of different spacing's

\begin{tabular}{|c|c|c|c|c|c|c|c|c|c|c|c|c|}
\hline \multirow[t]{2}{*}{ Treatments } & \multicolumn{4}{|c|}{ Grain Yield (kg/ha) } & \multicolumn{4}{|c|}{ Straw Yield (kg/ha) } & \multicolumn{4}{|c|}{ Harvest Index (\%) } \\
\hline & 2015 & 2016 & 2017 & Pooled & 2015 & 2016 & 2017 & Pooled & 2015 & 2016 & 2017 & Pooled \\
\hline T1- $30 \mathrm{~cm}$ spacing & 7515 & 7680 & 5640 & 6945 & 11122 & 11160 & 8124 & 10102 & 40.3 & 40.7 & 40.9 & 40.6 \\
\hline T2-25 cm spacing & 6540 & 6840 & 5435 & 6271 & 10202 & 10807 & 8533 & 9847 & 39.0 & 38.7 & 38.9 & 38.8 \\
\hline T3-20 cm spacing & 5850 & 6212 & 4845 & 5635 & 9385 & 10126 & 8097 & 9224 & 38.3 & 38.0 & 37.5 & 37.9 \\
\hline $\begin{array}{l}\text { T4-Farmers practice } \\
\text { (Delayed } \\
\text { transplanting) }\end{array}$ & 5512 & 5950 & 4650 & 5370 & 9509 & 10086 & 8022 & 9206 & 36.6 & 37.1 & 36.6 & 36.7 \\
\hline SEm \pm & 382 & 335 & 314 & 270 & 367 & 416 & 102 & 354 & 0.98 & 0.6 & 1.3 & 0.7 \\
\hline C.D. at $5 \%$ & 954 & 838 & 782 & 673 & 917 & 1032 & 245 & 878 & 2.40 & 1.5 & 2.0 & 1.8 \\
\hline
\end{tabular}

Table.4 Economics of rice was influenced by drum seeder under of different spacing's

\begin{tabular}{|c|c|c|c|c|c|c|c|c|c|c|c|c|}
\hline Treatments & \multicolumn{4}{|c|}{ Cost of Cultivation (Rs/ha) } & \multicolumn{4}{|c|}{ Goss Returns (Rs/ha } & \multicolumn{4}{|c|}{ Net Returns (Rs/ha) } \\
\hline & 2015 & 2016 & 2017 & Pooled & 2015 & 2016 & 2017 & Pooled & 2015 & 2016 & 2017 & Pooled \\
\hline T1- $30 \mathrm{~cm}$ spacing & 46254 & 47344 & 45640 & 46413 & 135270 & 138240 & 101520 & 125010 & 89016 & 90896 & 55880 & 78597 \\
\hline T2-25 cm spacing & 46748 & 47843 & 46453 & 47015 & 117720 & 123120 & 97830 & 112890 & 70972 & 75277 & 51377 & 65875 \\
\hline T3-20 cm spacing & 47250 & 48326 & 46856 & 47477 & 105300 & 111816 & 87210 & 101442 & 58050 & 63490 & 40454 & 53998 \\
\hline $\begin{array}{l}\text { T4-Farmers practice } \\
\text { (Delayed } \\
\text { transplanting) }\end{array}$ & 52540 & 53216 & 52876 & 52877 & 99216 & 107100 & 83700 & 96672 & 46676 & 53884 & 30824 & 43795 \\
\hline SEm \pm & 2317 & 2002 & 2470 & 2255 & 6750 & 5597 & 5504 & 4662 & 6940 & 6007 & 6170 & 4893 \\
\hline C.D. at 5\% & 5783 & 5402 & 6420 & 5854 & 17546 & 15112 & 14310 & 12120 & 18038 & 15614 & 15424 & 12722 \\
\hline
\end{tabular}




\section{Yield attributes}

The yield attributes were significantly affected by drum seeder under different spacing's. Significantly maximum number of Panicles/ $\mathrm{m}^{-2}$ (387.8), Length of Panicle (18.3 $\mathrm{cm}$ ), number of grains per panicle (186.7), Straw Yield (10102 kg/ha) and Harvest Index $(40.6 \%)$ were recorded with $30 \mathrm{~cm}$ spacing drum seeder $\left(\mathrm{T}_{1}\right)$ than other treatments and also in three seasons similar trend was observed by adopted $30 \mathrm{~cm}$ spacing drum seeder $\left(T_{1}\right)$ because facilitate weed free condition by power weeders drawn in between rows two times easily, resulted in better root establishment and formation of healthy tillers leads to produce higher yield attributes over other treatments, similar research finding were revealed by Halder et al., (2007). However $25 \mathrm{~cm}$ spacing drum seeder $\left(\mathrm{T}_{2}\right)$ was recorded significantly maximum number of Panicles/ $\mathrm{m}^{-2}$ (331.0), number of grains per panicle (182.3) and Harvest Index (38.8\%) than $\left(\mathrm{T}_{4}\right)$ Farmers practice as well as it was on par with $20 \mathrm{~cm}$ spacing $\left(T_{3}\right)$. The lowest yield attributes number of Panicles/ $\mathrm{m}^{-2}$ (286.4), Length of Panicle $(16.5 \mathrm{~cm})$, number of grains per panicle (174.6), Straw Yield (9206 kg/ha) and Harvest Index $(36.7 \%)$ recorded in $\left(\mathrm{T}_{4}\right)$ farmers practice due to delayed transplanting hence aged nursery seedlings were produced least number of tillers, panicles per unit area as well as no of grains per panicle leads to least Harvest Index. Similar research findings were reported by Shekar et al., (1991) and Sudip Chakraborthy et al., (2014).

\section{Yield and economics}

The yield and economics of drum seeding rice was significantly influenced by different spacing. Sowing of the rice with $30 \mathrm{~cm}$ spacing $\left(\mathrm{T}_{1}\right)$ was recorded significantly maximum grain yield $(6945 \mathrm{~kg} / \mathrm{ha})$ over all treatments due to maximum number of tillers, panicles per unit area and no of grains resulted in gave best yield followed by $\left(\mathrm{T}_{2}\right)$ $25 \mathrm{~cm}$ spacing $(6271 \mathrm{~kg} / \mathrm{ha})$, however it was on par with $20 \mathrm{~cm}$ spacing $\left(\mathrm{T}_{3}\right)$. The lowest yield $(5370 \mathrm{~kg} / \mathrm{ha})$ was recorded in farmers practice $\left(T_{4}\right)$ due to less tillers and no of panicles per unit area with delayed planting. Similar reports revealed by Shinde et al., (2005). Highest gross returns (125010/-) and monitory benefit returns (78597/-) per hectare were recorded by $30 \mathrm{~cm}$ spacing drum seeder $\left(\mathrm{T}_{1}\right)$ than all other treatments due to lowest cost of cultivation compared to farmers practice $\left(T_{4}\right)$ because direct sowing without nursery raise and manual transplanting reduced the cost of cultivation. However 25 $\mathrm{cm}$ spacing drum seeder $\left(\mathrm{T}_{2}\right)$ was also get significant gross return (112890/-) and net returns (65875/-) per hectare than farmer practice $\left(\mathrm{T}_{1}\right)$ and it was on par with $\left(\mathrm{T}_{3}\right)$. Lowest gross returns (96672/-) and monitory benefit net returns (43795/-) were observed with farmer practice $\left(T_{1}\right)$ than all other treatments due to aged nursery under delayed transplanting situation, cost of cultivation also higher (52877/-) than other treatments and timely uncontrolled weed growth during critical period of crop weed competition reduces the yield and yield attributes of rice there by drastically affected the monitory benefit returns. Similar results were reported by Sukla et al., (1984)

\section{References}

Baloach A.W, Soomro A.M, Javed M.A, Ahmed M, Bughio H.R, Bughio M.S, and Mastoi N.N, (2002) Optimum plant Density for High Yield in Rice (Oryza sativa L.,) Asian Journal of Plant Science Volume I Number 1: 25-27.

Halder J, and Patra A.K. (2007) Performance of 8-row drum seeder in direct seeded rice (Oryza sativa L.,) under puddle condition. Indian Journal of Agricultural Sciences, 77(12): 819-23. 
Padmaja K, and Reddy B.B, (1998) Effect of seedling density in nursery, age of seedling and geometry on growth and yield of hybrid rice during wet season. Oryza, 35 (4): 380-381.

Ponnuswamy K, Santhi P, Kempuchetty N, and Subramanium M. (1999) Effect of various methods of establishment on growth and yield of rice. Oryza. 36(3): 294-295.

Reddy G.V, and Reddy P.S.(1986) Effect of time of planting and spacing on IET2508 in puddle soil during dry season. Oryza, 23(1): 53-55.

Shekar J, and Singh C.M. (1991) Influence of methods and dates of stand establishment on growth and yield of rice Oryza, 28: 45-48.

Shinde D.R, Dixit A.J, and Thorat S.T. (2005) Response of Sahyadri hybrid rice to different spacing, seed rates and fertilizer levels under drilled condition in Konkan Region of Maharashtra.
Journal of Maharashtra Agric. University, 30(3): 357-359.

Singh G. Singh R.G, Singh O.P, Kumar T, Mehta R.K, Kumar V. and Singh P.P (2005) Effect of weed management practices on direct seeded rice (Oryza sativa) under puddle low lands. Indian Journal of Agronomy, 50(1): 35-37.

Sudip Chakraborthy, Biswas P.K, Roy T.S, Mahmud M.A.A, Mehraj H. and Jamal Uddin A.F.M. (2014). Growth and Yield of Boro Rice (BRRI Dhan 50) as affected by planting geometry under system of rice intensification, Journal of Bio Science and Agricultural Research, vol. 02(01): 36-43.

Sukla V.K, Sharma R.S, and Kewat B. (1984). Efeect of spacing and fertilizers levels on growth and yield of rice under late planting condition. Indian Journal of Agricultural Research. 18(3): 165167.

\section{How to cite this article:}

Srinivasa Rao, R., M. Venkatramulu, J. Hemantha Kumar and Raghurami Reddy, P. 2020. Evaluation of Drum Seeder in Rice (Oryza sativa L.) under Different Spacing's. Int.J.Curr.Microbiol.App.Sci. 9(04): 2765-2771. doi: https://doi.org/10.20546/ijcmas.2020.904.326 